\title{
Annotated Expressed Sequence Tags and cDNA Microarrays for Studies of Brain and Behavior in the Honey Bee
}

\author{
Charles W. Whitfield, ${ }^{1}$ Mark R. Band, ${ }^{3}$ Maria F. Bonaldo, ${ }^{2}$ Charu G. Kumar, ${ }^{3}$ \\ Lei Liu, ${ }^{3}$ Jose R. Pardinas, ${ }^{3}$ Hugh M. Robertson, ${ }^{1}$ M. Bento Soares, ${ }^{2}$ \\ and Gene E. Robinson ${ }^{1,4}$ \\ ${ }^{1}$ Department of Entomology and Neuroscience Program, University of Illinois, Urbana, Illinois 61801, USA; ${ }^{2}$ Departments \\ of Pediatrics and Biochemistry, University of lowa, lowa City, lowa 52242, USA; ${ }^{3}$ W.M. Keck Center for Comparative \\ and Functional Genomics, University of Illinois, Urbana, Illinois 61801, USA
}

\begin{abstract}
To accelerate the molecular analysis of behavior in the honey bee (Apis mellifera), we created expressed sequence tag (EST) and cDNA microarray resources for the bee brain. Over 20,000 cDNA clones were partially sequenced from a normalized (and subsequently subtracted) library generated from adult $A$. mellifera brains. These sequences were processed to identify 15,311 high-quality ESTs representing 8912 putative transcripts. Putative transcripts were functionally annotated (using the Gene Ontology classification system) based on matching gene sequences in Drosophila melanogaster. The brain ESTs represent a broad range of molecular functions and biological processes, with neurobiological classifications particularly well represented. Roughly half of Drosophila genes currently implicated in synaptic transmission and/or behavior are represented in the Apis EST set. Of Apis sequences with open reading frames of at least $450 \mathrm{bp}, 24 \%$ are highly diverged with no matches to known protein sequences. Additionally, over 100 Apis transcript sequences conserved with other organisms appear to have been lost from the Drosophila genome. DNA microarrays were fabricated with over 7000 EST cDNA clones putatively representing different transcripts. Using probe derived from single bee brain mRNA, microarrays detected gene expression for $90 \%$ of Apis CDNAs two standard deviations greater than exogenous control cDNAs.
\end{abstract}

[The sequence data described in this paper have been submitted to Genbank data library under accession nos. BI502708-BI517278. The sequences are also available at http:/ / titan.biotec.uiuc.edu/bee/ honeybee_project.htm.]

The honey bee (Apis mellifera) is an important model for studies of neural and behavioral plasticity, particularly with respect to social behavior, learning, and memory (Fahrbach and Robinson 1995; Robinson 1998; Menzel 2001; Maleszka et al. 2000). The neuroanatomy, neurophysiology, and neurochemistry of the honey bee brain have been studied extensively, and several functions have been mapped to particular brain regions (e.g., Menzel 2001; Fahrbach and Robinson 1995). Honey bees also have been used extensively to study the genetic underpinnings of behavior (Rothenbuhler 1967; Page and Robinson 1991). In the past few years, these lines of inquiry have been extended to the discovery of quantitative trait loci (Hunt et al. 1995, 1998) and analyses of expression levels of genes in the brain (Kucharski et al. 1998, 2000; Fiala et al. 1999; Toma et al. 2000; Shapira et al. 2001; Kucharski and Maleszka 2002).

One strong advantage of working with honey bees is that it is possible to study behavior under both laboratory and natural conditions. The natural social life of honey bees, though arguably as complex as in many vertebrate societies, can be extensively manipulated with precision. Insights gained from both lab and field studies ultimately will enable

${ }^{4}$ Corresponding author.

E-MAIL generobi@life.uiuc.edu; FAX (217) 244-3499.

Article and publication are at http://www.genome.org/cgi/doi/10.1101/ gr.5302. information on genes influencing neural and behavioral plasticity to be interpreted from ecological and evolutionary perspectives, contributing to a more comprehensive understanding of genes, brain, and behavior (Robinson 1999).

Molecular analyses in the honey bee have been constrained by the high investment required to identify and clone individual genes and the need to have an a priori hypothesis about each gene. The public databases contained only about 101 complete or near-complete $A$. mellifera gene sequences (nonredundant entries in SWISS-PROT and TrEMBL, as of December 2001) and, prior to this study, a total of 800 nucleotide sequences, most of them expressed sequence tags (ESTs) from antennae (H.M.R., unpubl.) or larvae (Evans and Wheeler 2001). The value of studying many genes simultaneously in the honey bee was demonstrated by Evans and Wheeler (2001) who identified gene expression profiles that were characteristic for worker/queen caste differentiation. This study involved the initial identification of 158 candidate clones using subtractive methods, and was thus limited by the small number of genes analyzed. Current DNA microarray technologies allow expression studies of many thousands of genes at the same time (Schena et al. 1995; DeRisi et al. 1997). ESTs provide an economical approach to identifying large numbers of genes that can be used in gene expression and other genomic studies (reviewed by Gerhold and Caskey 1996; see also Dimopoulos et al. 2000 and Porcel et al. 2000). 
Here, we describe a collection of more than 20,000 ESTs generated from the $A$. mellifera brain, putatively representing 8912 different transcripts after sequence assembly. To facilitate gene identification and functional genomic studies in the honey bee, the brain EST set has been annotated using the structured vocabulary provided by the Gene Ontology Consortium (2001), based on molecular studies of gene function in Drosophila melanogaster. We describe a DNA microarray resource composed of over 7000 EST cDNA clones putatively representing different transcripts. We demonstrate the utility of this resource by reporting on gene expression measured in single honey bee brains. Additionally, comparative genomics approaches were used to predict or improve predictions for 122 genes in Drosophila, as well as to identify 126 genes conserved between Apis and other organisms that apparently have been lost from the Drosophila genome.

\section{RESULTS AND DISCUSSION}

\section{Generation and Assembly of Brain ESTs}

A normalized, unidirectional cDNA library was generated from dissected honey bee brains. An initial 7968 clones were sequenced from the $5^{\prime}$ end. The library was then subtracted, and 12,288 more clones were sequenced (also from the $5^{\prime}$ end). An additional 1152 sequences ( $3^{\prime}$ and duplicate $5^{\prime}$ ends) were obtained from previously sequenced clones. Thus, the EST set represents 20,256 cDNA clones and 21,408 total sequences. The 21,408 sequences were trimmed of vector and low-quality sequence and filtered for minimum length (200 bp), identifying 15,311 high-quality ESTs of 494 bp average length (Table 1). The estimated number of ESTs per putative transcript was initially 1.2 when sequencing was initiated and rose to 1.7 at the time sequencing was terminated (based on phrap analyses of high-quality ESTs after each batch of sequences; see below).

The 15,311 high-quality ESTs were analyzed with the CAP3 assembly program to identify those that represent redundant transcripts (Table 2; see Table 8 for all program references). A total of 9481 ESTs were assembled into 3136 contiguous sequences (contigs). The remaining 5830 ESTs did not assemble into contigs (referred to as singlets). Thus, the combined set of contigs and singlets included 8966 sequences (hereafter referred to as "assembled sequences"), putatively representing different transcripts. Only 40 contig sequences contained more than 10 ESTs, and the largest number of ESTs assembled into one contig was 44 .

We separately processed the high-quality ESTs using PHRAP and CAP3 using different levels of stringency (Table 2). These different assemblies produced very similar results, and we retained the CAP3 results for further analyses. Fifty-four assembled sequences were removed from the database (se-

Table 1. Honey Bee Brain EST Summary

$\begin{array}{cr}\text { Total sequences } & 21408 \\ \text { CDNA clones sequenced (5' end) } & 20256 \\ \text { Normalized library } & 7968 \\ \text { Normalized/subtracted library } & 12288 \\ \text { Redundant 5' end sequences } & 960 \\ \text { 3' end sequences } & 192 \\ \text { Total high-quality sequences } & 15311\end{array}$

EST, expressed sequence tag.
Table 2. EST Assembly Results

\begin{tabular}{lrrr}
\hline & PHRAP $^{\mathbf{a}}$ & CAP3 $^{\mathbf{b}}$ & CAP3 $^{\mathbf{c}^{\circ}}$ \\
\hline Total sequences analyzed & 14642 & 14642 & 15311 \\
Number of ESTs in contigs & 8464 & 8357 & 9481 \\
$\begin{array}{l}\text { Number of contigs } \\
\text { Number of singlets }\end{array}$ & 3119 & 2910 & 3138 \\
$\begin{array}{l}\text { Number of putative transcripts } \\
\quad \text { (assembled sequences) }\end{array}$ & 6178 & 6285 & 5830 \\
$\begin{array}{l}\text { Number of contigs containing: } \\
\text { 2-4 ESTs }\end{array}$ & 9297 & 9196 & 8966 \\
5-10 ESTs & N/A & 2626 & 2762 \\
11-20 ESTs & N/A & 255 & 334 \\
$21-40$ ESTs & N/A & 28 & 33 \\
$>40$ ESTs & N/A & 2 & 6 \\
\hline
\end{tabular}

${ }^{a}$ Default settings

bHigh-quality ESTs assembled using high-quality, vector-trimmed sequence only. Default settings were used except minimum overlap was $40 \mathrm{bp}$ and $95 \%$ identity (default is $30 \mathrm{bp}, 75 \%$ identity). 'High-quality ESTs assembled using high- and low-quality, vectortrimmed sequence, $3^{\prime}$ and reductant $5^{\prime}$ ESTs were included (these were treated as independent clone sequences to avoid error resulting from manual clone picking). Default settings were used except minimum overlap was $40 \mathrm{bp}$. These assembly results were used for all analyses in this study, except where noted.

EST, expressed sequence tag.

quencing artifacts and/or exogenous contaminants; see Methods), leaving 8912 assembled sequences used in subsequent analyses.

\section{EST Quality Analysis and Sequence Survey}

Of the 8912 assembled sequences, 3501 (39\%) were similar to known protein sequences in the Non-Redundant Protein (nr) database (BLASTX; $E \leq 10^{-5}$ ). To estimate the proportion of transcript sequences that represent truly novel genes, the assembled sequences were screened to identify only those with clear protein coding capacity. A total of 3449 assembled sequences have an open reading frame (ORF) of at least $450 \mathrm{bp}$. Of these, 2616 (76\%) had matches in the nr database and 833 (24\%) had no matches (Fig. 1A). This result indicates that perhaps $24 \%$ of the protein-encoding genes expressed in the honey bee brain are highly diverged in primary structure. A total of 5463 assembled sequences did not have an ORF of at least $450 \mathrm{bp}$; of these, 885 (16\%) had matches in the nr database and 4578 (84\%) had no matches. Many assembled sequences did not have an ORF of $450 \mathrm{bp}$ because they were too short (916 assembled sequences were $<450$ bp long). Other assembled sequences may have lacked an ORF for a variety of reasons, including frame shift errors, $5^{\prime}$ truncation of cDNA clones (causing ESTs to consist mostly or entirely of $3^{\prime}$ untranslated region [UTR]) or ESTs that were not derived from mRNA. Microarray hybridization results indicated that the vast majority of ESTs were derived from legitimate transcripts (see below). To assess $5^{\prime}$ truncation of cDNA clones, we examined sequence alignments of 130 ESTs $\left(5^{\prime}\right)$ that had matches to A. mellifera full-length cDNA sequences in GenBank (matches defined as $\geq 98 \%$ identity over at least $200 \mathrm{bp}$ ). Nine of these clones were in a backwards orientation (see below). Of the 121 ESTs in a forward orientation, 56 (46\%) had 5 ' sequences that corresponded to the 5 ' end of the fulllength cDNA sequence. The remaining 65 ESTs (54\%) were derived from 5 ' truncated cDNA inserts. This result suggests that a large fraction of noncoding ESTs may have been de- 
A
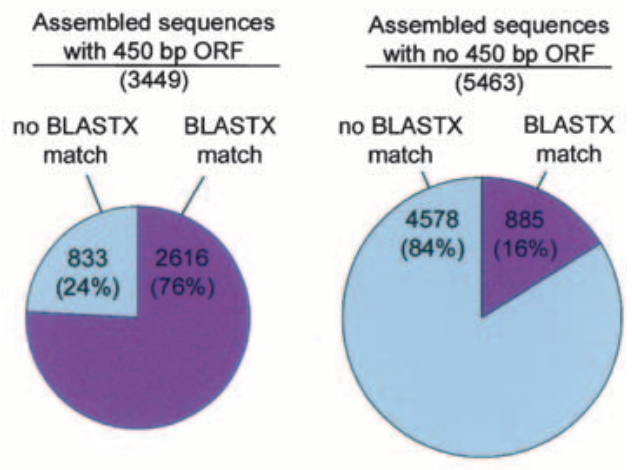

B Best BLASTX match for assembled sequences

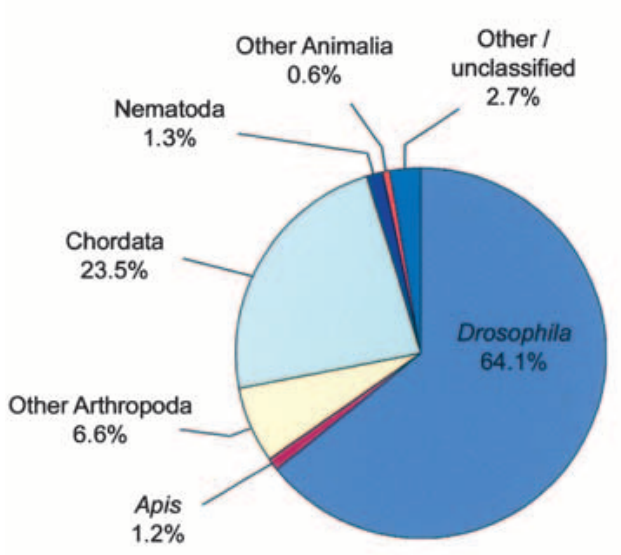

C All BLASTX matches for assembled sequences

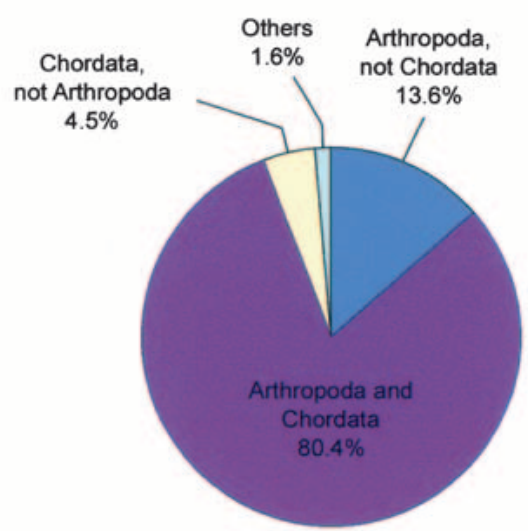

Figure 1 Open reading frame (ORF) and BLASTX results. $(A)$ The proportion of assembled sequences with and without BLASTX matches in the Non-Redundant Protein (nr) database $\left(E \leq 10^{-5}\right)$ is indicated for assembled sequences with and without an identified $450 \mathrm{bp}$ ORF. Relative area of pie charts indicates number of sequences. (B) Apis sequences with matches in the $\mathrm{nr}$ database (3501 total) were classified by the organism of the "best hit" protein sequence. (C) Apis sequences with matches in the nr database (3501 total) were separately analyzed for matches in Arthropoda and Chordata protein databases (see Table 8 for sub-database creation). rived from severely truncated cDNAs consisting mostly or entirely of 3' UTR.

ESTs were analyzed to identify a variety of other possible artifacts (see Methods). We estimated that $10 \%$ of the clones in the library are at least partially unspliced (often resulting from priming of the oligo(dT) primer within an unspliced AT-rich intron). Approximately $18 \%$ of the cDNA clones appear to be inserted in a reverse orientation. Finally, a single chimeric clone was identified that contained linker sequence within an EST flanked by back-to-back poly $(\mathrm{A})^{+}$sequences. No chimeras were identified by comparing BLASTX matches for $3^{\prime}$ and $5^{\prime}$ ESTs corresponding to the same cDNA clones (68 clones with $3^{\prime}$ and 5' BLASTX matches were tested).

Figure 1B summarizes the top hits (matches with lowest $E$ value) for each of the 3501 assembled sequences that had matches in the nr database. As expected, the majority (2245; $64 \%)$ were most similar to predicted protein sequence from Drosophila. Only $41(1.2 \%)$ were most similar to predicted protein sequence from Apis (because of the small number of Apis gene sequences in the database). An additional 230 $(6.6 \%)$ were most similar to sequence from a variety of other Arthropoda, including the insects Bobyx mori (28 best matches) and Manduca sexta (27 best matches). A surprisingly large number, 823 (24\%), were most similar to sequence from Chordata (see Comparative Genomics, below). Others were most similar to proteins from Nematoda (47) or other Animalia (22). Twenty had best matches to various bacterial proteins with amino acid identities ranging from $42 \%$ to $92 \%$ (specifically, Mycobacterium [15], Caulobacter [4], and Agrobacterium [1]). We suggest that these 20 sequences were derived from unknown bacterial infections or contamination of bee brains or associated tissues. Two sequences appeared to be derived from an uncharacterized virus, having $24 \%$ and 39\% aminoacid identity to different regions of the 2858 amino-acid polyprotein of the honey bee sacbrood virus.

Separate BLASTX searches of Arthropoda and Chordata protein databases revealed that the majority of assembled sequences with matches $(80 \%)$ were similar to predicted protein sequences from both Arthropoda and Chordata (Fig. 1C). Others were similar to sequences from Arthropoda but not Chordata (13.6\%), from Chordata but not Arthropoda (4.5\%), or from non-Arthropoda and non-Chordata organisms only (1.6\%). The implications of these findings for Drosophila were investigated further (see Comparative Genomics, below).

The assembled EST database was searched for simple sequence repeats using BLASTN and a database of simple sequence repeats of one to four bases (excluding $(A)_{n}$ repeat). This search identified simple sequence repeats in 767 of the assembled sequences using a highest scoring pair (HSP) cutoff value of 50, and 76 sequences using an HSP cutoff value of 100 . These HSP cutoff values roughly correspond to 25 and 50 bp of perfect match, respectively (note that identified repeats are not necessarily contiguous because default BLAST parameters allow gaps in alignment). Repeat sequences are likely to reside primarily in EST noncoding sequence (which constitute a large fraction of the ESTs, see above).

\section{Gene Number}

EST assembly is expected to generate an overestimation of the actual number of genes represented, as failure of ESTs to assemble can result from nonoverlapping ESTs, alternate splicing, sequence polymorphism, and sequencing errors. Assuming approximately one-to-one correspondence between genes 
in Apis and Drosophila, the level of redundancy can be estimated based on BLASTX searches of Drosophila predicted proteins. A total of 3362 Apis assembled sequences had "best hits" to 2672 different Drosophila sequences, suggesting 19.6\% redundancy in the Apis assembled sequence set. Similar levels of redundancy after EST assembly have been estimated in other large EST collections (e.g., roughly $20 \%$ in a large mouse cDNA set; see Kawai et al. 2001). Taking 20\% as an estimate of redundancy in the 8912 assembled Apis sequences, the EST set may represent a total of 7100 genes expressed in the honey bee brain. If Apis has about the same number of genes as does Drosophila, this would represent roughly $50 \%$ of the total number of genes in the Apis genome.

A similar estimate of representation was provided by comparison of the 8912 assembled sequences with a set of 101 full- or near-full-length cDNA sequences obtained from an independent honey bee brain library (sequences kindly provided by R. Maleszka). A total of 55 assembled sequences from the EST set matched 54 different cDNA sequences from the independent brain library (match defined as $\geq 98 \%$ nucleotide identity over $200 \mathrm{bp}$ ). This result suggested that (based on this small sample set of 101 brain expressed cDNA sequences) the chance of finding a gene in the EST set was about $54 \%$.

\section{Functional Annotation of Bee Brain ESTs}

We characterized the $A$. mellifera EST sequences with respect to functionally annotated genes in Drosophila melanogaster, taking advantage of the fact that this insect genome has been sequenced and extensively annotated (Adams et al. 2000). Each Apis assembled sequence was tentatively assigned Gene Ontology (GO) classification based on annotation of the

Table 3. Molecular Function

\begin{tabular}{|c|c|c|c|}
\hline Gene ontology term & $\begin{array}{c}\text { Drosophila } \\
\text { genes }^{\mathrm{a}}\end{array}$ & $\begin{array}{l}\text { Apis assembled } \\
\text { sequences }^{\text {b }}\end{array}$ & $\begin{array}{c}\text { Drosophila } \\
\text { genes represented }\end{array}$ \\
\hline All molecular function terms & 6260 & 1958 & 1509 \\
\hline nucleic acid binding & 1052 & 353 & 269 \\
\hline DNA binding & 696 & 186 & 144 \\
\hline transcription factor & 495 & 132 & 104 \\
\hline RNA binding & 265 & 125 & 92 \\
\hline translation factor & 72 & 40 & 32 \\
\hline transcription factor binding & 37 & 18 & 12 \\
\hline cell-cycle regulator & 17 & 6 & 6 \\
\hline chaperone & 114 & 50 & 35 \\
\hline motor & 74 & 31 & 22 \\
\hline microtubule binding & 83 & 41 & 28 \\
\hline defense/immunity protein & 46 & 8 & 6 \\
\hline enzyme & 2916 & 949 & 752 \\
\hline GTPase & 92 & 51 & 42 \\
\hline kinase & 355 & 133 & 108 \\
\hline phosphatase & 171 & 52 & 41 \\
\hline peptidase & 491 & 110 & 93 \\
\hline enzyme activator & 61 & 21 & 20 \\
\hline enzyme inhibitor & 74 & 7 & 7 \\
\hline apoptosis activator & 3 & 1 & 1 \\
\hline apoptosis inhibitor & 10 & 3 & 3 \\
\hline signal transducer & 677 & 193 & 141 \\
\hline receptor & 443 & 107 & 70 \\
\hline ligand-dependent nuclear receptor & 22 & 9 & 7 \\
\hline transmembrane receptor & 400 & 79 & 55 \\
\hline G-protein coupled receptor & 207 & 21 & 17 \\
\hline olfactory receptor & 58 & 1 & 1 \\
\hline receptor signaling protein & 161 & 76 & 61 \\
\hline ligand & 71 & 9 & 9 \\
\hline cell adhesion & 53 & 27 & 17 \\
\hline storage protein & 7 & 0 & 0 \\
\hline structural protein & 354 & 106 & 92 \\
\hline transporter & 792 & 296 & 195 \\
\hline ion channel & 141 & 72 & 46 \\
\hline voltage-gated ion channel & 43 & 29 & 16 \\
\hline neurotransmitter transporter & 13 & 14 & 6 \\
\hline ligand binding or carrier & 1095 & 451 & 335 \\
\hline protein tagging & 6 & 5 & 3 \\
\hline antioxidant & 8 & 7 & 5 \\
\hline
\end{tabular}

Classification is hierarchical: indented terms are children of parent terms listed above.

Genes may be assigned to more than one term. Also note that child terms may have more than one parent term (e.g., "ligand-dependent nuclear receptor" is a child of both "receptor" and "transcription factor") (see The Gene Ontology Consortium 2001)

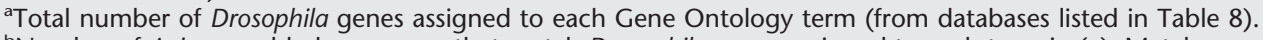

${ }^{b}$ Number of Apis assembled sequences that match Drosophila genes assigned to each term in (a). Match means that the Drosophila gene was "best hit" for the Apis sequence (and e-value $\leq 10^{-5}$ ).

"Number of different Drosophila genes matched by Apis sequences. 
single "best hit" match in BLASTX searches of Drosophila predicted proteins $\left(E \leq 10^{-5}\right)$. Functional assignments of Apis ESTs described here are at the "inferred from electronic annotation" (IEA) level of evidence (see The Gene Ontology Consortium 2001). We take a conservative approach and avoid using Drosophila annotations that are, themselves, assigned at the IEA level of evidence. We do not exclude Drosophila annotations that are assigned at the "inferred from sequence similarity" (ISS) level of evidence (which requires human judgment and is therefore a higher level of evidence than IEA).

Tables 3 and 4 summarize assignments of Apis sequences to major molecular functions and biological processes, respectively. A broad range of functions and processes are represented in the brain ESTs. Table 5 lists Apis sequences that match Drosophila genes implicated in synaptic transmission (GO:0007268). Fifty-four (out of 116) Drosophila genes implicated in synaptic transmission were "best hit" for at least one Apis-assembled sequence. Table 6 lists Apis sequences that match Drosophila genes implicated in behavior. Note that current GO annotation for Drosophila includes only 42 genes implicated in behavior (as of December 2001). To provide information for comparative analysis, we generated a list of 106 genes directly implicated in behavior based on mutant analysis and/or transgenic experiments in Drosophila (compiled from FlyBase and J. Hall, pers. comm.). Genes were listed if at least one mutant allele or transgene affected a specific aspect of behavior, such as rhythmicity, mating, feeding, or learning and memory. (Global locomotor effects such as paralysis, uncoordinated movement, or shaking were not considered in this analysis, although many of the genes listed do exhibit global locomotor or lethal phenotypes when mutated to the null state.) Using this criteria, 47 (out of 106) Drosophila behavior genes were "best hit" for at least one Apis-assembled sequence. Annotation of Apis EST sequences with respect to all GO terms for molecular function, biological process, and cellular component are regularly updated and can be accessed at http://titan.biotec.uiuc.edu/bee/honeybee_project.htm.

We expect that ongoing improvements in GO annotation for Drosophila, human, mouse, and Caenorhabditis elegans will lead to significant improvements in Apis gene annotation in the near future. The current annotation of Apis sequences, based solely on matches to Drosophila proteins, allowed useful comparative analyses but had several drawbacks. We often found Apis sequences that clearly encoded members of important gene families of known function, but nevertheless were not annotated. In every case examined, this occurred because the "best hit" gene in Drosophila was not yet assigned GO annotation. Conversely, Apis sequences sometimes were assigned function based on fairly weak matches (i.e., close to the $E$-value cutoff of $10^{-5}$ ), resulting from the short length of the Apis EST. Annotation also was limited by a high proportion of ESTs in this project that contain transcript noncoding sequence (e.g., 3' UTR). Additional ESTs, especially from full-

Table 4. Biological Process

\begin{tabular}{|c|c|c|c|}
\hline Gene Ontology term & $\begin{array}{l}\text { Drosophila } \\
\text { genes }\end{array}$ & $\begin{array}{l}\text { Apis assembled } \\
\text { sequences }\end{array}$ & $\begin{array}{l}\text { Drosophila genes } \\
\text { represented }\end{array}$ \\
\hline All biological process terms & 2746 & 906 & 696 \\
\hline cell growth and maintenance & 2102 & 766 & 597 \\
\hline metabolism & 1493 & 531 & 424 \\
\hline protein metabolism and modification & 887 & 300 & 239 \\
\hline ion homeostasis & 7 & 9 & 6 \\
\hline intracellular protein traffic & 158 & 88 & 67 \\
\hline vesicle transport & 150 & 83 & 62 \\
\hline synaptic vesicle transport & 108 & 67 & 48 \\
\hline stress response & 120 & 22 & 16 \\
\hline response to external stimulus & 390 & 73 & 51 \\
\hline cell organization and biogenesis & 253 & 108 & 79 \\
\hline cell cycle & 187 & 42 & 34 \\
\hline apoptosis & 29 & 2 & 2 \\
\hline cell communication & 772 & $25 \overline{7}$ & $17 \overline{8}$ \\
\hline cell adhesion & 46 & 25 & 15 \\
\hline cell recognition & 43 & 33 & 20 \\
\hline neuronal cell recognition & 14 & 3 & 3 \\
\hline synaptic target recognition & 5 & 2 & 2 \\
\hline signal transduction & 274 & 84 & 67 \\
\hline cell-cell signaling & 117 & 79 & 54 \\
\hline synaptic transmission & 116 & 79 & 54 \\
\hline neurotransmitter release & 111 & 71 & 50 \\
\hline developmental processes & 406 & 153 & 106 \\
\hline embryogenesis and morphogenesis & 227 & 99 & 67 \\
\hline neurogenesis & 95 & 59 & 36 \\
\hline imaginal discs development & 63 & 35 & 27 \\
\hline sex determination & 8 & 4 & 3 \\
\hline dosage compensation & 8 & 6 & 4 \\
\hline metamorphosis & 6 & 3 & 2 \\
\hline physiological processes & 30 & 6 & 3 \\
\hline perception external stimulus & 196 & 31 & 23 \\
\hline behavior & 42 & 18 & 15 \\
\hline
\end{tabular}


Table 5. Apis Matches to Drosophila Synaptic Transmission Genes

\begin{tabular}{|c|c|c|c|c|c|}
\hline Apis sequence & Drosophila gene & $\begin{array}{l}\text { Alignment } \\
\text { length (aa) }\end{array}$ & HSP & e-value & Identities \\
\hline Contig276 & amphiphysin & 295 & 390 & $1 \mathrm{E}-108$ & $65 \%$ \\
\hline BB160003A10D03 & $A P-47$ & 251 & 411 & $1 \mathrm{E}-115$ & $82 \%$ \\
\hline ВВ170001B10Н02 & $A P-50$ & 234 & 407 & $1 \mathrm{E}-115$ & $88 \%$ \\
\hline ВB160013В20B02 & Arf51F & 172 & 349 & $1 \mathrm{E}-96$ & $97 \%$ \\
\hline Contig 1946 & Arf72A & 179 & 340 & $8 \mathrm{E}-94$ & $93 \%$ \\
\hline BB160006B10F12 & Arf79F & 171 & 344 & $2 \mathrm{E}-95$ & $98 \%$ \\
\hline BB170032A10C06 & BCDNA:LD23336 & 200 & 95 & $3 \mathrm{E}-20$ & $30 \%$ \\
\hline BB170005A10D08 & CaMKII & 59 & 123 & $1 \mathrm{E}-28$ & $96 \%$ \\
\hline BB160014B20D10 & Caps & 225 & 372 & $1 \mathrm{E}-103$ & $77 \%$ \\
\hline Contig2785 & $C d k 5$ & 264 & $44 \overline{3}$ & $1 \mathrm{E}-125$ & $80 \%$ \\
\hline BB160022A10H03 & CG10617 & 93 & 61 & $6 \mathrm{E}-10$ & $40 \%$ \\
\hline BB16000BA20A11 & CG1107 & 121 & 137 & $6 \mathrm{E}-33$ & $55 \%$ \\
\hline Contig 1704 & CG14296 & 178 & 335 & $2 \mathrm{E}-92$ & $91 \%$ \\
\hline BB170005B20G04 & CG15694 & 149 & 212 & $2 \mathrm{E}-55$ & $63 \%$ \\
\hline Contig1152 & CG17762 & 186 & 92 & $3 \mathrm{E}-19$ & $33 \%$ \\
\hline Contig 1768 & CG2381 & 201 & 399 & $1 \mathrm{E}-111$ & $91 \%$ \\
\hline Contig2868 & CG2903 & 51 & 62 & $3 \mathrm{E}-10$ & $47 \%$ \\
\hline ВВ170016А20В10 & CG3020 & 38 & 53 & $2 \mathrm{E}-09$ & $57 \%$ \\
\hline Contig2061 & CG3029 & 210 & 340 & $1 \mathrm{E}-93$ & $81 \%$ \\
\hline Contig190 & CG5014 & 89 & 101 & $2 \mathrm{E}-38$ & $58 \%$ \\
\hline BB160022A20H05 & CG5627 & 220 & 263 & $7 \mathrm{E}-71$ & $60 \%$ \\
\hline BB170011A20D07 & CG5678 & 164 & 287 & $3 \mathrm{E}-78$ & $85 \%$ \\
\hline BB160024A20D05 & CG7034 & 199 & 202 & $2 \mathrm{E}-52$ & $51 \%$ \\
\hline ВB160003В20B01 & CG7127 & 235 & 130 & $8 \mathrm{E}-31$ & $37 \%$ \\
\hline Contig2640 & CG7321 & 213 & 192 & $2 \mathrm{E}-49$ & $49 \%$ \\
\hline ВB160020B10H05 & CG7736 & 208 & 115 & $1 \mathrm{E}-42$ & $37 \%$ \\
\hline BB160009A10E12 & CG8608 & 131 & 198 & $4 \mathrm{E}-51$ & $70 \%$ \\
\hline Contig1193 & Che & 295 & 446 & $1 \mathrm{E}-126$ & $74 \%$ \\
\hline Contig924 & Csp & 237 & 218 & $4 \mathrm{E}-57$ & $51 \%$ \\
\hline BB160022A10D06 & Dap160 & 202 & 155 & $3 E-38$ & $46 \%$ \\
\hline BB170019A20D08 & dlg1 & 266 & 377 & $1 \mathrm{E}-105$ & $72 \%$ \\
\hline Contig1272 & gammaSnap & 247 & 283 & $8 \mathrm{E}-77$ & $55 \%$ \\
\hline BB160010B20F08 & Gdi & 109 & 181 & $3 \mathrm{E}-46$ & $75 \%$ \\
\hline BВ160015B20E03 & $\mathrm{I}(2) \mathrm{gl}$ & 193 & 96 & $1 \mathrm{E}-20$ & $33 \%$ \\
\hline Contig1207 & lqf & 102 & 66 & $3 \mathrm{E}-11$ & $45 \%$ \\
\hline ВB170026B10H11 & Nrx & 142 & 215 & $9 \mathrm{E}-57$ & $67 \%$ \\
\hline Contig1277 & Nsf2 & 108 & 148 & $9 \mathrm{E}-37$ & $66 \%$ \\
\hline ВВ170025В20H08 & $n-s y b$ & 73 & 135 & $2 \mathrm{E}-32$ & $91 \%$ \\
\hline Contig1852 & Rab3 & 198 & 367 & $1 \mathrm{E}-102$ & $89 \%$ \\
\hline Contig2442 & Rop & 147 & 222 & $8 \mathrm{E}-59$ & $70 \%$ \\
\hline Contig1960 & Sed5 & 150 & 141 & $4 \mathrm{E}-34$ & $50 \%$ \\
\hline Contig734 & Snap & 279 & 427 & $1 \mathrm{E}-120$ & $72 \%$ \\
\hline BB170015A10F09 & Snap24 & 32 & 51 & $4 \mathrm{E}-07$ & $78 \%$ \\
\hline BB160017B20C04 & Stam & 219 & 253 & $5 \mathrm{E}-68$ & $57 \%$ \\
\hline Contig2134 & syt & 330 & 559 & $1 \mathrm{E}-160$ & $85 \%$ \\
\hline Contig80 & SytIV & 190 & 274 & $6 \mathrm{E}-74$ & $70 \%$ \\
\hline
\end{tabular}

length, enriched, normalized, and subtracted libraries (e.g., Carninci et al. 2000), would enhance Apis gene annotation by allowing more ESTs to be assembled into larger contig sequences.

\section{Honey Bee Brain Microarray}

To allow functional genomic studies of brain and behavior in the honey bee, we generated cDNA microarrays from the annotated EST set described above. A total of 7329 cDNAs (putatively representing different transcripts) were successfully amplified as "single-band" PCR product and spotted on the microarray. Pilot studies indicated that fluorescent probe derived from single-brain mRNA (amplified by in vitro transcription; see Methods) could be used to label the vast majority of Apis cDNA spots on the microarray. Data obtained from one microarray experiment are presented in Table 7 and Figure 2.
In this experiment, two dissected adult bee brains were combined and mixed during homogenization, then split into two equal samples. Each of the two samples was used to generate an independent probe (one Cy5-labeled probe [635 $\mathrm{nm}$ ] and one Cy3-labeled probe [532 nm]). The two probes were combined and hybridized to a single microarray. A total of 7300 and 7305 cDNAs produced hybridization signal at least two standard deviations (SD) greater than background at 635 and $532 \mathrm{~nm}$, respectively. To determine whether this hybridization signal was specific, we compared signal produced by Apis cDNA spots with exogenous negative control cDNA spots on the microarray (derived from vertebrate and plant genes). A total of 6647 (91\%) and 6631 (90\%) of the Apis cDNAs produced signal at least two standard deviations greater than exogenous control cDNAs at 635 and $532 \mathrm{~nm}$, respectively. Signal intensities between 635 and $532 \mathrm{~nm}$ were highly corre- 
Table 6. Apis Matches to Drosophila Behavior Genes

\begin{tabular}{|c|c|c|c|c|c|}
\hline Apis sequence & Drosophila gene & $\begin{array}{l}\text { Alignment } \\
\text { length (aa) }\end{array}$ & HSP & e-value & Identities \\
\hline Contig3015 & 14-3-3zeta & 246 & 452 & $1 \mathrm{E}-127$ & $91 \%$ \\
\hline ВВ170004В20H03 & acj6 & 45 & 92 & $2 \mathrm{E}-19$ & $97 \%$ \\
\hline BB160024A10A12 & Adar & 169 & 185 & $3 \mathrm{E}-47$ & $54 \%$ \\
\hline Contig 1753 & $a p$ & 83 & 143 & $2 \mathrm{E}-34$ & $81 \%$ \\
\hline Contig467 & ari-1 & 55 & 103 & $1 \mathrm{E}-22$ & $81 \%$ \\
\hline BB170007B20D03 & Atpalpha & 97 & 177 & $3 \mathrm{E}-45$ & $89 \%$ \\
\hline BB160016A10E02 & CadN & 126 & 117 & $4 \mathrm{E}-27$ & $47 \%$ \\
\hline Contig2335 & Cam & 145 & 228 & $5 \mathrm{E}-60$ & $74 \%$ \\
\hline BB170005A10D08 & CaMKII & 59 & 123 & $1 \mathrm{E}-28$ & $96 \%$ \\
\hline BB170029A10F02 & Cha & 87 & 55 & $4 \mathrm{E}-08$ & $36 \%$ \\
\hline BB170016A10D05 & chp & 32 & 47 & $5 \mathrm{E}-06$ & $62 \%$ \\
\hline BB160005A10C01 & Cova & 144 & 151 & $3 \mathrm{E}-37$ & $53 \%$ \\
\hline Contig924 & Csp & 237 & 218 & $4 \mathrm{E}-57$ & $51 \%$ \\
\hline BB170022A10F08 & dare & 155 & 101 & $1 \mathrm{E}-32$ & $38 \%$ \\
\hline Contig377 & Dat & 167 & 113 & $9 \mathrm{E}-26$ & $39 \%$ \\
\hline ВВ170029B10С01 & $d n c$ & 66 & 120 & $8 \mathrm{E}-29$ & $84 \%$ \\
\hline BB160007B10G06 & $d s x$ & 47 & 50 & $2 \mathrm{E}-06$ & $46 \%$ \\
\hline Contig1083 & $e$ & 147 & 86 & $2 \mathrm{E}-17$ & $36 \%$ \\
\hline BB160017B10B10 & Fas2 & 199 & 189 & $1 \mathrm{E}-48$ & $47 \%$ \\
\hline BB160010A10H12 & for & 193 & 291 & $2 \mathrm{E}-79$ & $75 \%$ \\
\hline BB170016A20G06 & fru & 103 & 168 & $3 \mathrm{E}-42$ & $76 \%$ \\
\hline BB160008B10H11 & G-salpha60A & 234 & 357 & 4E-99 & $73 \%$ \\
\hline BB1 70024A20D07 & $H k$ & 28 & 52 & $4 \mathrm{E}-07$ & $78 \%$ \\
\hline Contig12 & lark & 367 & 380 & $1 \mathrm{E}-106$ & $58 \%$ \\
\hline ВВ170007B10A02 & mas & 167 & 340 & $4 \mathrm{E}-94$ & $94 \%$ \\
\hline Contig923 & mle & 375 & 355 & $3 E-98$ & $50 \%$ \\
\hline Contig362 & $n b A$ & 159 & 70 & $2 \mathrm{E}-12$ & $33 \%$ \\
\hline BB160015B10F09 & Nf1 & 210 & 226 & $1 \mathrm{E}-59$ & $57 \%$ \\
\hline BB170031B10G07 & $\operatorname{nin} a A$ & 172 & 212 & $2 \mathrm{E}-55$ & $55 \%$ \\
\hline BB170001A10G09 & ninaE & 163 & 239 & $1 \mathrm{E}-63$ & $69 \%$ \\
\hline BB170022A10G08 & nompC & 161 & 101 & $4 \mathrm{E}-22$ & $40 \%$ \\
\hline BB160020B20C08 & para & 34 & 76 & $1 \mathrm{E}-14$ & $97 \%$ \\
\hline Contig730 & Pka-C1 & 197 & 402 & $1 \mathrm{E}-112$ & $95 \%$ \\
\hline BB160004A20E12 & plx & 53 & 82 & $3 \mathrm{E}-16$ & $71 \%$ \\
\hline Contig397 & Pp1-87B & 141 & 282 & $1 \mathrm{E}-76$ & $94 \%$ \\
\hline BB170012A20E10 & $r d g B$ & 160 & 58 & $4 \mathrm{E}-09$ & $28 \%$ \\
\hline Contig 2777 & $\operatorname{Reg}-5$ & 90 & 69 & $3 \mathrm{E}-12$ & $40 \%$ \\
\hline BB160003A20A12 & Rya-r44F & 197 & 316 & $2 \mathrm{E}-89$ & $73 \%$ \\
\hline BВ160013А20B02 & $s b b$ & 53 & 52 & $2 \mathrm{E}-06$ & $54 \%$ \\
\hline BB160004A10F11 & sd & 260 & 360 & $1 \mathrm{E}-100$ & $68 \%$ \\
\hline Contig830 & sgg & 285 & 522 & $1 \mathrm{E}-148$ & $87 \%$ \\
\hline Contig3064 & Shab & 88 & 98 & $3 E-21$ & $59 \%$ \\
\hline Contig 1958 & Shal & 72 & 95 & $3 \mathrm{E}-20$ & $58 \%$ \\
\hline Contig2624 & slo & 90 & 184 & $5 E-47$ & $95 \%$ \\
\hline Contig2399 & tipE & 64 & 107 & 7E-24 & $78 \%$ \\
\hline Contig1139 & vri & 247 & 99 & $2 \mathrm{E}-21$ & $30 \%$ \\
\hline Contig2819 & $w$ & 68 & 108 & $2 \mathrm{E}-56$ & $73 \%$ \\
\hline
\end{tabular}

Behavior genes defined in text. Drosophila genes tested but not found: Ace, Acp70A, Adf1, amn, bi, Btk29A, Caki, Ca-alpha1D, clk, CrebB-17A, Crg-1, crl, cry, cyc, Cyp4e2, dco, Ddc, disco, Dr, dsf, dy, eag, gk, G-oalpha65A, Hdc, inaC, lat, lio, lush, Iz, mnb, mud, mys, ninaC, nompA, nompB, nonA, norpA, ogre, otu, Pdf. per, Pka-R1, ppl, qtc, rb, rut, scb, Sh, Shaw, shi, sol, spin, sws, tim, to, tutl, Ubc47D,W.

lated in this experiment $(r=0.9926)$ indicating that technical variation (from RNA isolation, mRNA amplification by in vitro transcription, and fluorescent labeling of probe) is very low. Results from additional microarrays were qualitatively similar using different bee brains as source material (data not shown). These results indicate that genomic scale gene expression profiling is feasible in single honey bee brains using the microarrays and protocols described here.

Microarray hybridization data have been used for the validation of gene sequences (e.g., Andrews et al. 2000; Shoemaker et al. 2001). The results presented above indicate that the vast majority of bee ESTs were derived from legitimate brain-expressed gene transcripts.

\section{Comparative Genomics in Apis and Drosophila}

A total of 823 of the assembled sequences (24\% of those with matches) were most similar to protein sequence from Chordata (Fig. 1B). The high level of Apis "best hits" to Chordata could arise from a high rate of sequence divergence or gene loss in Drosophila and/or be related to deficiencies in Drosophila gene prediction. To distinguish between these possibilities, Drosophila genome sequence and EST databases were 
Table 7. Signal analysis of an example microarray

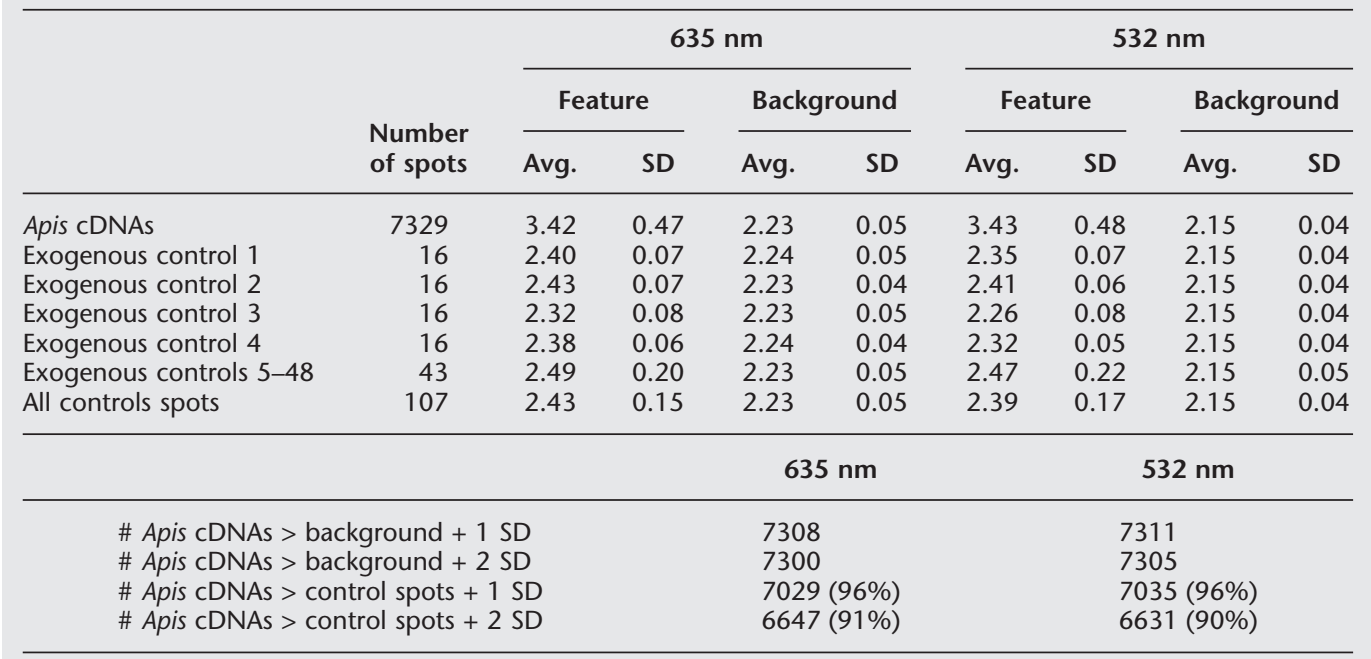

All inteneity values were $\log 10$ transformed. Feature and background readings are indicated for each CDNA spot (based on median pixel intensity) for 635 and $532 \mathrm{~nm}$ wavelengths. Average (Avg.) and standard deviation (SD) are indicated. Exogenous controls are described in Methods.

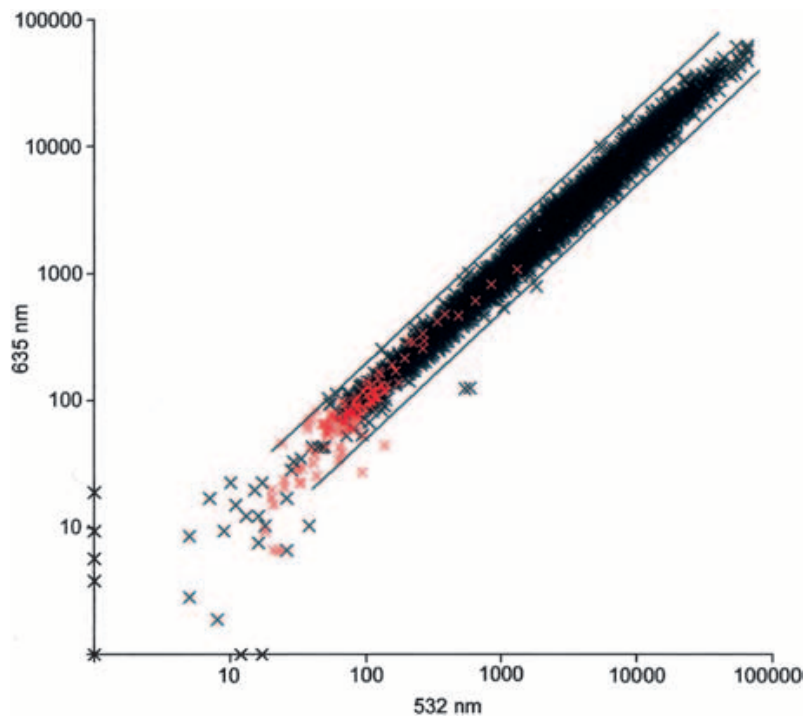

Figure 2 Signal intensities from an example microarray. Values plotted are feature minus background intensity at 635 and $532 \mathrm{~nm}$ wavelengths for each cDNA spot (see Methods). Values were normalized such that the median ratio $(635: 532 \mathrm{~nm})$ equals 1.0. Apis CDNAs are shown as black $x$ 's, exogenous negative control cDNAs are shown as red x's. Cy3-labeled probe $(532 \mathrm{~nm})$ and Cy5-labeled probe (635 $\mathrm{nm}$ ) were independently derived from the same starting sample (using in vitro transcription to amplify starting mRNA; see Methods). The starting sample consisted of a mixture of two dissected adult bee brains (one bee observed foraging and one bee observed caring for brood). The coefficient of correlation ( $r$ ) between 635 and $532 \mathrm{~nm}$ values was 0.9926 (based on log-transformed values). Divergence of values from the diagonal $($ ratio $=1)$ reflects technical variation introduced during RNA isolation, mRNA amplification by in vitro transcription, and fluorescent labeling of probe. The two diagonal bars indicate ratios $(635: 532 \mathrm{~nm})$ equal to 0.5 and 2.0 . searched for matches to Apis-assembled sequences using TBLASTX. Matches were screened individually to identify true gene alignments based on plausible exon structure and amino-acid composition. In 99 cases, predicted proteins in Drosophila were missing one or more exons (predicted by alignment between Apis ESTs and Drosophila genome sequence). This caused a weak or no match to the Drosophilapredicted protein sequence and a misleading "best hit" to Chordata. In 23 cases, genes were identified in Drosophila genomic sequence (based on alignment with Apis sequence) that were not represented in Drosophila predicted protein or EST databases. Suggestions for annotations of these 122 Drosophila genes have been communicated to FlyBase.

Of the 701 remaining cases where the best match for the Apis sequence was to Chordata, 574 (16\% of Apis-assembled sequences with matches) had likely orthologs in Drosophila, but these Drosophila genes were so diverged that better matches for the Apis sequences were identified in human, mouse and/or other non-Arthropoda. In 126 cases (3.6\% of Apis assembled sequences with matches), the Apis sequence had significant and clear matches to proteins from human, mouse and/or other organisms, but no plausible ortholog was identified in searches of Drosophila-predicted protein, genome, or EST databases. These Apis sequences appear to define genes that have been lost from the Drosophila genome. Detailed analysis of these highly diverged genes and gene loss events in Drosophila will be presented in a subsequent manuscript.

\section{Future Prospects}

The relationship between genes and behavior is complex and is only beginning to be understood. Honey bees exhibit a wide variety of behavioral phenomena that are not observed in Drosophila, such as kin recognition, complex communication via the dance language, socially regulated division of labor, and a larger variety of forms of learning. The honey bee also is haplodiploid and has the highest known recombination rate of any animal (Hunt and Page 1995), traits that can

\section{Genome Research}


to-back poly $(\mathrm{A})^{+}$tails or vector linker sequences within ESTs. BLASTN searches for these instances identified only one chimera (out of all 21,408 ESTs). In this instance the 3' linker sequence was found in the middle of an EST, flanked by backto-back poly $(\mathrm{A})^{+}$tails from two different transcripts. Furthermore, in all cases where $3^{\prime}$ ESTs had BLASTX matches (E $\leq 10^{-20}$ ) to a Drosophila predicted protein (68 cases), 5' ESTs from the same cDNA matched the same Drosophila protein. To estimate the total number of backward cDNA inserts, singlet ESTs with BLASTX matches to Drosophila-predicted proteins were analyzed. Out of 1919 singlet EST matches, 364 (19\%) had a negative reading frame, indicating a backward cDNA insert. Of 720 individually analyzed ESTs with BLASTX matches to proteins from other organisms, $72(10 \%)$ had clear instances of unspliced intron sequence (based on alignment with putative orthologs, ORF analysis, and identification of putative splice junctions); many of these clones appear to have resulted from priming of the oligo(dT) primer within an unspliced AT-rich intron.

ESTs were assembled using CAP3 and phrap (see Table 2 for settings).

ORFs were identified using FLIP with the minimum length set to 150 amino acids $(450 \mathrm{bp})$. All BLAST searches were conducted on a desktop PC or local server using standalone BLAST software and sequence databases indicated in Table 8 . All $E$-value cutoffs were $10^{-5}$, except where indicated otherwise. GO databases were installed on a local server. A GO browser was designed and implemented at the W.M. Keck Center for Comparative and Functional Genomics (University of Illinois at Urbana-Champaign) and used for functional annotation of the assembled EST sequences.

\section{Microarray Fabrication}

A single EST cDNA clone was selected to represent each assembled sequence (putatively unique transcript). For contigs with multiple ESTs, the rule followed was to select the 3 '-most EST that had at least $300 \mathrm{bp}$ of high-quality sequence. This procedure biases the cDNAs on the microarray toward the $3^{\prime}$ end but ensures that at least $300 \mathrm{bp}$ of cDNA is spotted on the array. A total of $8872 \mathrm{cDNA}$ clones were selected. These clones were picked from the library stock plates (384-well bacteria clones) and rearrayed to a new set of 384-well plates. These clones were grown overnight followed by sequence verification (see Clone Tracking, below).

Creation of the microarrays was essentially as described by Brown and Botstein (1999). Bacteria clones were inoculated to 96-well plates with LB and Amp and grown overnight. Plasmid inserts were amplified by PCR using $1 \mu \mathrm{L}$ of the overnight bacteria inoculant and modified M13 (5'CCAGTCACGACGTTGTAAAACGAC-3') and M13 reverse (5'GTGTGGAATTGTGAGCGGATAACAA-3') primers in $50 \mu \mathrm{L}$ volume reactions. Amplifications were performed in a $\mathrm{MJ}$ PTC-200 thermocycler (MJ Research). PCR reaction mixes contained $5 \mu \mathrm{L} 10 \mathrm{x}$ reaction buffer $(100 \mathrm{mM}$ Tris- $\mathrm{HCl}, \mathrm{pH} 8.3$, $500 \mathrm{mM} \mathrm{KCl}$ ), $2.0 \mathrm{mM} \mathrm{MgCl}_{2}, 100 \mu \mathrm{M}$ dNTPs, $0.2 \mu \mathrm{M}$ each primer, and $1 \mathrm{U}$ Amplitaq Gold (Perkin Elmer). An initial 9-min denaturation was followed by 35 cycles of 40 sec denaturation at $94^{\circ} \mathrm{C}, 40 \mathrm{sec}$ annealing at $65^{\circ} \mathrm{C}$, and $3.5 \mathrm{~min}$ elongation at $72^{\circ} \mathrm{C}$. The reaction ended with an additional incubation of $5 \mathrm{~min}$ at $72^{\circ} \mathrm{C}$. Products were cleaned using Sephadex G-50 columns. Five microliters of each clean PCR product was analyzed on a $1 \%$ agarose gel. cDNA amplification products were visually examined and subjectively classified as follows: "strong single band" (86\%), "weak or absent band" (13\%), or "multiple bands" (1\%). Only cDNAs that were amplified as "single strong band" and successfully spotted on the array (see below) were used in subsequent data analysis (7329 total).

PCR products were dried and resuspended in $8 \mu \mathrm{L} 3 \mathrm{x}$ SSC, $1.5 \mathrm{M}$ betaine. Betaine was used as in Diehl et al. (2001) to improve spot homogeneity and to increase hybridization signal on the microarray. All cDNAs were printed as single spots on Telechem Superamine slides (Arrayit) using a Cartesian Technologies spotter. Exogenous control cDNAs derived from cattle (phosphoglycerate kinase 1 and $\beta$-2-microglobulin) and soy (rubisco small chain 1 and chlorophyll ab binding protein) were spotted on the array 16 times each, such that they were represented on each of the 16 subgrids on the microarray ("exogenous controls 1-4", respectively, in Table 7). An additional 43 vertebrate-derived cDNAs (singly spotted at random positions throughout the microarray) were used as control spots ("exogenous controls 5-48" in Table 7).

Spot and printing quality were assessed visually after printing. cDNA spots do not fully evaporate after arraying (as a result of $1.5 \mathrm{M}$ betaine) allowing inspection of spot morphology under a dissecting scope. A few slides (about one in every five) exhibited minor defects (e.g., a single spot missing or several spots damaged by dust or lint particles). The majority of slides exhibited no defects (no spots missing, no spots joined, and all spots uniform in size).

DNA was crosslinked to slides by baking at $80^{\circ} \mathrm{C}$ for $1 \mathrm{~h}$. Slides were blocked in $0.2 \%$ SDS for $4 \mathrm{~min}$, followed by two washes in water. Slides were denatured in boiling water for 2 min, spun dry, and stored.

\section{Microarray Hybridization, Scanning, and Data Analyses}

Frozen brains were dissected from bees of known age and behavioral state as above. mRNA was amplified exactly as in Baugh et al. (2001), using only one round of in vitro transcription. Amplified RNA (aRNA) was analyzed by spectrophotometer and gel electrophoresis. Negative control reactions (no template and genomic DNA only) conducted in parallel produced no aRNA. aRNA was labeled by reverse transcription as follows: $5 \mu \mathrm{g}$ of aRNA was mixed with $5 \mu \mathrm{g}$ of random primer (Roche) (10 $\mu \mathrm{L}$ volume), denatured at $70^{\circ} \mathrm{C}$ for $4 \mathrm{~min}$, and placed on ice. Labeling reaction $\left(6 \mu \mathrm{L}\right.$ of $5 \mathrm{x} 1^{\text {st }}$ Strand Buffer [Gibco]; $3 \mu \mathrm{L}$ of $100 \mathrm{mM}$ DTT; $6 \mu \mathrm{L}$ of low T dNTPs [2.5 $\mathrm{mM}$ each dATP, dCTP, dGTP and $1.0 \mathrm{mM}$ dTTP] (Sigma), $3 \mu \mathrm{L}$ of $1 \mathrm{mM}$ Cy3- or Cy5-dUTP [Amersham Pharmacia] and $2 \mu \mathrm{L}$ of $200 \mathrm{U} / \mu \mathrm{L}$ SuperScript II [Gibco]) was prepared on ice, mixed with aRNA and primer, then incubated at $42^{\circ} \mathrm{C}$ for $1 \mathrm{~h}$. One microliter of SuperScript II was added and the reaction was incubated at $42^{\circ} \mathrm{C}$ for an additional hour. RNA was removed by adding $1 \mu \mathrm{L}$ of $0.25 \mathrm{mg} / \mathrm{mL}$ RNAse A (NEB) and 0.5 $\mu \mathrm{L}$ of $2 \mathrm{U} / \mu \mathrm{L}$ RNAse $\mathrm{H}$ (Stratagene) and incubating at $37^{\circ} \mathrm{C}$ for 30 min. Labeled cDNA was purified using the Qiagen PCR Purification Kit.

Thirty microliters of purified, labeled cDNA was mixed with blocking oligos dT-T7 (20 $\mu$ g; see Baugh et al. (2001)) and $\mathrm{dT}_{30}(40 \mu \mathrm{g})$, boiled for $3 \mathrm{~min}$, allowed to anneal at $60^{\circ} \mathrm{C}$ for $10 \mathrm{~min}$ and then room temperature for $10 \mathrm{~min}$, mixed with an equal volume of $2 x$ hybridization buffer ( $50 \%$ formamide, $10 \mathrm{x}$ SSC, and $0.2 \%$ SDS), and then hybridized to microarray at $42^{\circ} \mathrm{C}$ overnight. Excess probe was removed by a series of $4 \mathrm{~min}$ washes in $1 \mathrm{x}$ SSC, $0.2 \%$ SDS at $42^{\circ} \mathrm{C} ; 0.1 \mathrm{x} \mathrm{SSC}, 0.2 \%$ SDS at room temperature; and 0.1x SSC at room temperature. Slides were scanned using an Axon 4000B scanner, and images were analyzed with GenePix software.

All data analyses were conducted using log-transformed values (median pixel intensities) generated by the GenePix software.

\section{Clone Tracking}

To identify and correct possible errors in clone tracking, 420 cDNA clones (of the initial set of 20,256) were resequenced from the stock bacterial 384-well plates. Two clones were selected from different positions from each 96-well quadrant (there are four quadrants per 384-well plate). These sequences

\section{Genome Research}


were tested against existing EST sequences in the database. A PERL script was used to identify expected matches, possible lane-tracking errors, quadrant or plate swaps, or errors in quadrant or plate orientation. In the majority of cases, one or two sequences were obtained from each quadrant and matched expected database sequences, thus confirming tracking accuracy. In cases where a sequence was not obtained or did not match the expected sequence, two additional clones were grown and sequenced. Tracking errors affecting whole quadrants were indicated for 16 (of 212 total) quadrants, including quadrant swaps, duplicate sequencing of quadrants, and quadrants in which database sequences were in an upside-down orientation with respect to the actual clones. The exact nature of each quadrant error was determined (in all cases, the initial determination was confirmed by additional sequencing) and corresponding sequence entrees in the database were corrected to reflect their true plate positions. Lanetracking errors (i.e., ABI 377 generated sequences that drift from one lane into a neighboring lane) were not observed.

After rearraying the 8872 clones to be used for the microarray, an additional 192 cDNA clones were regrown and sequenced to verify tracking integrity (two clones were picked from each 96-well quadrant, as above). From these, 136 highquality sequences were obtained and tested for identity with the expected EST. Only one sequence of the 136 tested did not match the expected EST, suggesting that clone tracking was close to $99 \%$ accurate at this stage.

\section{ACKNOWLEDGMENTS}

We thank L. Hood and D. Smoller for helpful discussions; A.J. Ross, S. O'Brien, and A. Cziko for bee collections; S. O'Brien for bee brain dissections; D. Toma for RNA extraction; M. Rebeiz for assistance with PERL programming; A. Cziko for assistance in microarray fabrication; and R. Hoskins, S. Clough, and members of the Robinson lab for reviewing the manuscript. Special thanks to H.A. Lewin, Director of the Keck Center, for excellent advice throughout the project and his tireless and creative efforts to facilitate genomics research on this campus. This research was supported by an NSF Postdoctoral Fellowship in Bioinformatics (C.W.W.) and grants from the University of Illinois Critical Research Initiatives Program and the Burroughs Wellcome Trust (G.E.R.).

The publication costs of this article were defrayed in part by payment of page charges. This article must therefore be hereby marked "advertisement" in accordance with 18 USC section 1734 solely to indicate this fact.

\section{REFERENCES}

Adams, M.D., Celniker, S.E., Holt, R.A., Evans, C.A., Gocayne, J.D., Amanatides, P.G., Scherer, S.E., Li, P.W., Hoskins, R.A., Galle, R.F., et al. 2000. The genome sequence of Drosophila melanogaster. Science 287: 2185-2195.

Andrews, J., Bouffard, G.G., Cheadle, C., Lu, J., Becker, K.G., and Oliver, B. 2000. Gene discovery using computational and microarray analysis of transcription in the Drosophila melanogaster testis. Genome Res. 10: 2030-2043.

Baugh, L.R., Hill, A.A., Brown, E.L., and Hunter, C.P. 2001. Quantitative analysis of mRNA amplification by in vitro transcription. Nucleic Acids Res. 29: E29.

Bonaldo, M.F., Lennon, G., and Soares, M.B. 1996. Normalization and subtraction: Two approaches to facilitate gene discovery. Genome Res. 6: 791-806.

Brillet, C., Robinson, G.E., Bues, R., and Le Conte, Y. 2001. Racial differences in division of labor in colonies of the honey bee, Apis Mellifera. Ethology 2002. In press.

Brown, P.O. and Botstein, D. 1999. Exploring the new world of the genome with DNA microarrays. Nat. Genet. 21: 33-37.

Capaldi, E.A., Smith, A.D., Osborne, J.L., Fahrbach, S.E., Farris, S.M., Reynolds, D.R., Edwards, A.S., Martin, A., Robinson, G.E., Poppy, G.M., et al. 2000. Ontogeny of orientation flight in the honeybee revealed by harmonic radar. Nature 403: 537-540.

Carninci, P., Shibata, Y., Hayatsu, N., Sugahara, Y., Shibata, K., Itoh, M., Konno, H., Okazaki, Y., Muramatsu, M., and Hayashizaki, Y. 2000. Normalization and subtraction of cap-trapper-selected cDNAs to prepare full-length cDNA libraries for rapid discovery of new genes. Genome Res. 10: 1617-1630.

DeRisi, J.L., Iyer, V.R., and Brown, P.O. 1997. Exploring the metabolic and genetic control of gene expression on a genomic scale. Science 278: 680-686.

Diehl, F., Grahlmann, S., Beier, M., and Hoheisel, J.D. 2001. Manufacturing DNA microarrays of high spot homogeneity and reduced background signal. Nucleic Acids Res. 29: E38.

Dimopoulos, G., Casavant, T.L., Chang, S., Scheetz, T., Roberts, C., Donohue, M., Schultz, J., Benes, V., Bork, P., Ansorge, W., et al. 2000. Anopheles gambiae pilot gene discovery project: Identification of mosquito innate immunity genes from expressed sequence tags generated from immune-competent cell lines. Proc. Natl. Acad. Sci.USA 97: 6619-6624.

Evans, J.D. and Wheeler, D.E. 2001. Expression profiles during honeybee caste determination. Genome Biol. 2: research0001.1-0001.6.

Fahrbach, S.E. and Robinson, G.E. 1995. Behavioral development in the honey bee: Toward the study of learning under natural conditions. Learn Mem. 2: 199-224.

Fiala, A., Muller, U., and Menzel, R. 1999. Reversible downregulation of protein kinase A during olfactory learning using antisense technique impairs long-term memory formation in the honeybee, Apis mellifera. J. Neurosci. 19: 10125-10134.

The Gene Ontology Consortium. 2001. Creating the gene ontology resource: Design and implementation. Genome Res. 11: 1425-1433.

Gerhold, D. and Caskey, C.T. 1996. It's the genes! EST access to human genome content. Bioessays 18: 973-981.

Huang, X. and Madan, A. 1999. CAP3: A DNA sequence assembly program. Genome Res. 9: 868-877.

Hunt, G.J., Guzman-Novoa, E., Fondrk, M.K., and Page, R.E., Jr. 1998. Quantitative trait loci for honey bee stinging behavior and body size. Genetics 148: 1203-1213.

Hunt, G.J. and Page, R.E., Jr. 1995. Linkage map of the honey bee, Apis mellifera, based on RAPD markers. Genetics 139: 1371-1382.

Hunt, G.J., Page, R.E., Jr., Fondrk, M.K., and Dullum, C.J. 1995. Major quantitative trait loci affecting honey bee foraging behavior. Genetics 141: 1537-1545.

Kawai, J., Shinagawa, A., Shibata, K., Yoshino, M., Itoh, M., Ishii, Y., Arakawa, T., Hara, A., Fukunishi, Y., Konno, H., et al. 2001. Functional annotation of a full-length mouse cDNA collection. Nature 409: 685-690.

Kucharski, R., Ball, E.E., Hayward, D.C., and Maleszka, R. 2000. Molecular cloning and expression analysis of a cDNA encoding a glutamate transporter in the honey bee brain. Gene 242: 399-405.

Kucharski, R. and Maleszka, R. 2002. Evaluation of differential gene expression during behavioral development in the honeybee using microarrays and northern blots. Genome Biol. 3: research0007.1-0007.9.

Kucharski, R., Maleszka, R., Hayward, D.C., and Ball, E.E. 1998. A royal jelly protein is expressed in a subset of Kenyon cells in the mushroom bodies of the honey bee brain. Naturwissenschaften 85: $343-346$.

Maleszka, R., Helliwell, P., and Kucharski, R. 2000. Pharmacological interference with glutamate re-uptake impairs long-term memory in the honeybee, Apis mellifera. Behav. Brain Res. 115: 49-53.

Menzel, R. 2001. Searching for the memory trace in a mini-brain, the honeybee. Learn. Mem. 8: 53-62.

Omholt, S.W., Rishovd, S., Elmholdt, O., Dalsgard, B., and Fromm, S. 1995. Successful production of chimerical honeybee larvae. J. Exp. Zool. 272: 410-412.

Page, R.E. and Robinson, G.E. 1991. The genetics of division of labour in honey bee colonies. Adv. Insect. Physiol. 23: 117-171.

Pellett, F.C. 1938. History of American beekeeping. Collegiate Press, Ames, Iowa.

Porcel, B.M., Tran, A.N., Tammi, M., Nyarady, Z., Rydaker, M., Urmenyi, T.P., Rondinelli, E., Pettersson, U., Andersson, B., and Aslund, L. 2000. Gene survey of the pathogenic protozoan Trypanosoma cruzi. Genome Res. 10: 1103-1107.

Robinson, G.E. 1992. The regulation of division of labor in insect societies. Annu. Rev. Entomol. 37: 637-665.

Robinson, G.E. 1998. From society to genes with the honey bee. Amer. Sci. 86: 456-462.

Robinson, G.E. 1999. Integrative animal behaviour and sociogenomics. Trends Ecol. Evol. 14: 202-205. 
Whitfield et al.

Robinson, K.O., Ferguson, H.J., Cobey, S., Vaessin, H., and Smith, B.H. 2000. Sperm-mediated transformation of the honey bee, Apis mellifera. Insect Mol. Biol. 9: 625-634.

Ronglin, Y., Hagen, A., and Omholt, S.W. 1997. Cryopreservation of totipotent nuclei from honeybee (Apis mellifera) embryos by rapid freezing. Cryobiology 35: 41-45.

Rothenbuhler, W.C. 1967. Genetic and evolutionary considerations of social behavior of honeybees and some related insects. In Behavior-genetic analysis (ed. J. Hirsch), pp. 61-106. McGraw-Hill, New York.

Schena, M., Shalon, D., Davis, R.W., and Brown, P.O. 1995. Quantitative monitoring of gene expression patterns with a complementary DNA microarray. Science 270: $467-470$.

Shapira, M., Thompson, C.K., Soreq, H., and Robinson, G.E. 2001. Changes in neuronal acetylcholinesterase gene expression and division of labor in honey bee colonies. J. Mol. Neurosci. 17: $1-12$.

Shoemaker, D.D., Schadt, E.E., Armour, C.D., He, Y.D., Garrett-Engele, P., McDonagh, P.D., Loerch, P.M., Leonardson, A., Lum, P.Y., Cavet, G., et al. 2001. Experimental annotation of the human genome using microarray technology. Nature 409: 922-927.

Toma, D.P., Bloch, G., Moore, D., and Robinson, G.E. 2000. Changes in period mRNA levels in the brain and division of labor in honey bee colonies. Proc. Natl. Acad. Sci. USA 97: 6914-6919.

Winston, M.L. 1987. The biology of the honey bee. Harvard University Press, Cambridge, Massachusetts.

\section{WEB SITE REFERENCES}

http://titan.biotec.uiuc.edu/bee/honeybee_project.htm.

http://www.fruitfly.org; Berkeley Drosophila Genome Project (BDGP).

http://www.geneontology.org; The Gene Ontology Consortium (2001).

http://www.genome.washington.edu/UWGC; University of Washington Genome Center.

http://megasun.bch.umontreal.ca/ogmpproj.html; Organelle Genome Megasequencing Project, University of Montreal. http://www.ncbi.nim.nih.gov; National Center for Biotechnology Information (NCBI)

http://www.neurobiologie.fu-berlin.de/Menzel.html

Received January 2, 2002; accepted in revised form February 14, 2002.

\section{Genome Research}




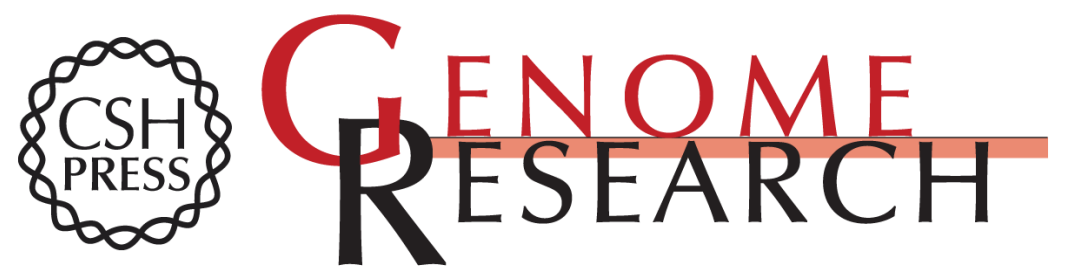

\section{Annotated Expressed Sequence Tags and cDNA Microarrays for Studies of Brain and Behavior in the Honey Bee}

Charles W. Whitfield, Mark R. Band, Maria F. Bonaldo, et al.

Genome Res. 2002 12: 555-566

Access the most recent version at doi:10.1101/gr.5302

References This article cites 34 articles, 17 of which can be accessed free at:

http://genome.cshlp.org/content/12/4/555.full.html\#ref-list-1

\section{License}

Email Alerting Receive free email alerts when new articles cite this article - sign up in the box at the Service top right corner of the article or click here.

\section{Affordable, Accurate Sequencing.}

